\title{
Bovine Herpesvirus 4 in Parana State, Brazil: case report, viral isolation, and molecular identification
}

\author{
Ernesto Renato Kruger ${ }^{1,6}$, Tania Regina Penha ${ }^{2,6}$, Daura Regina Eira Stoffelo ${ }^{3}$, \\ Paulo Michel Roehe ${ }^{4}$, Magda Costa Ribeiro ${ }^{5}$, Vanete Thomaz Soccol ${ }^{6}$ \\ ${ }^{1}$ Centro de Diagnóstico Marcos Enrietti, Curitiba, PR, Brazil. \\ ${ }^{2}$ Instituto de Tecnologia do Paraná, Curitiba, PR, Brazil. \\ ${ }^{3}$ Centro de Microscopia Eletrônica, Universidade Federal do Paraná, Curitiba, PR, Brazil. \\ ${ }^{4}$ Departamento de Microbiologia, Universidade Federal do Rio Grande do Sul, Porto Alegre, RS, Brazil. \\ ${ }^{5}$ Departamento de Patologia Básica, Centro Politécnico, \\ Universidade Federal do Paraná, Curitiba, PR, Brazil. \\ ${ }^{6}$ Programa de Pós Graduação em Processos Biotecnológicos, \\ Universidade Federal do Paraná, Curitiba, PR, Brazil.
}

Submitted: September 4, 2013; Approved: June 6, 2014

\begin{abstract}
Bovine Herpesvirus 4 (BoHV-4) is a member of Gammaherpesvirinae sub-family and belongs to genus Rhadinovirus. This virus has been associated with different clinical manifestations and research activity has put forward a strong correlation among virus infection, postpartum metritis, and abortion. The goal of this work was to characterize a virus strain isolate from a cow's uterine outflow. From swabs drawn of uterine secretion, a virus strain was isolated and characterized by its cytopathology, morphology, and molecular biology approaches. In culture there was CPE development, characterized mainly by long strands with several small balloons along them, radiated from infected cells. Electron microscopy analysis revealed virus particles that had icosahedrical capsid symmetry surrounded by a loose envelope, typical of a herpesvirus. A 2,571 bp PCR product after HindIII digestion generated four fragments, whose base pair composition were 403, 420, 535, and $1,125 \mathrm{bp}$. Restriction enzymes HindIII and BamHI generated the expected diagnostic bands as well as a 2,350 bp hypermolar fragment as a result of BamHI treatment to demonstrate that agent was a bovine herpesvirus 4, appertaining to DN-599 group.
\end{abstract}

Key words: BoHV-4 virus, PCR, RFLP, fingerprint.

Bovine herpesvirus 4 (BoHV-4) was first isolated by Bartha in Hungary from calves suffering from respiratory and ocular diseases (Bartha et al., 1966). The second major achievement that established a close association between this virus and bovine populations was the recovery of a herpesvirus by Mohanty in the United States from a 1.5 -year-old steer with clinical signs of respiratory illness (Mohanty et al., 1971). It is worth mentioning the works done by Theodoridis et al. (1978) in Africa with several strains of herpesvirus isolates from animals showing a genital syndrome known as "epivag," first described in 1938, but the serological relationship is now accepted as refer- ence strains, and it was not pursued. The successive isolations of viruses in several countries that share genomic and antigenic properties with BoHV-4, offer the ground for a non reasonless understanding that this pathogen has worldwide distribution.

Parks and Kendrick (1973) are considered the first researchers to isolate BoHV-4 from a cow with metritis, establishing a link between virus infection and uterus pathology. Since then several authors have signaled the virus BoHV-4 from samples of cattle with signs of reproductive disorders as Castrucci et al. (1986) in Italy, Mehrotra et al. (1986) in India, Czaplick and Thiry (1988) in Belgium,

Send correspondence to V.T. Soccol. Programa de Pós Graduação em Processos Biotecnológicos, Universidade Federal do Paraná, Rua Francisco H. dos Santos100, 81531-990 Curitiba, PR, Brazil. E-mail: vanetesoccol@gmail.com, vasoccol@ufpr.br. 
Frazier et al. (2001) in the United States, Monge et al. (2006) in Spain, Nikolin et al. (2007) in Serbia, and Verna et al. (2008) in Argentina. Donofrio et al. (2007) shed more light on the etiological role of BoHV-4 and indicated in his paper the likelihood of this virus being responsible for uterine pathology considering its tropism for stromal and epithelial cells and consequent cytopathology.

Molecular and genome sequencing data has allowed the classification of BoHV-4 as a gammaherpesvirus, genus Rhadinovirus (Zimmerman et al., 2001). Its genome is constituted of linear double-stranded DNA of $144 \pm 6 \mathrm{kbp}$, which consists of a long unique region (LUR) of $\pm 108 \mathrm{kbp}$ that has at both ends approximately 15 tandem repeats of $200 \mathrm{bp}$, totaling $\pm 2.2 \mathrm{kbp}$, a noncoding region named polyrepetitive DNA (prDNA) (Ehlers et al., 1985).

Through restriction enzyme analysis, strains of BoHV-4 have been grouped into three categories: i) DN599-like, similar to the strain DN599, reference in United States; ii) Movar-like, those strains similar to Movar 33/63; and iii) unclassified strains, which have their own profile particularities (Markine Goriaynoff et al., 2003).

In this short report, we describe the isolation and characterization by biological, morphological, and molecular methodologies of a herpesvirus from a cow suffering from postpartum metritis.

In a beef cattle farm located in the rural region of the Tibagi municipality (2430'34' S, 50²4'49” W) in Paraná state, southern Brazil, a herd of 320 females at reproductive age experienced elevated abortion occurrence. The rate of reproductive disorder was not available. The abortions occurred from 4 to 7 months' gestation. A total of four serum samples and vaginal discharge swabs were collected from cows with overt clinical manifestation for diagnostic purposes. We followed a standard viral isolation protocol, and we have no information about any other reproductive disease diagnostic that may have been requested by practitioners' veterinarians. Swabs containing uterine secretion drawn from cows with post-parturient metritis were shaken in $10 \mathrm{~mL}$ of F10-199 medium and clarified by centrifugation $\left(10,500 \mathrm{~g}\right.$ for $10 \mathrm{~min}$ at $\left.4{ }^{\circ} \mathrm{C}\right)$, and the supernatants of each sample were diluted to $1: 10$.

A cell lineage named TraFB, derived from a primary culture of a bovine fetus tracheal epithelium, was developed as a part of diagnostic activities from one of the authors (Kruger E. R.) at the virology laboratory of the Centro de Diagnóstico Marcos Enrietti - Paraná State, Brazil and was used for virus-isolation procedures. These cells were grown in an F10-199 medium (1:1) supplemented with $10 \%$ tryptose broth phosphate (TPB) and 5\% fetal bovine serum (FBS). The medium contained penicillin at $100 \mathrm{UI} \mathrm{mL}$, streptomycin at $100 \mu \mathrm{g} / \mathrm{mL}$, and amphotericin B at $2.5 \mu \mathrm{g} / \mathrm{mL}$.

Five $\mathrm{mL}$ of the supernatant were inoculated onto nearly confluent monolayer cells in $25 \mathrm{~cm}^{2}$ culture bottles and incubated for $1 \mathrm{~h}$ at $37^{\circ} \mathrm{C}$ in a $5 \% \mathrm{CO}_{2}$ incubator. Next, the inoculum was removed, the monolayer was washed with phosphate buffered saline (PBS), and $10 \mathrm{~mL}$ of growth medium were added. The same procedure was performed with a bottle containing only a maintenance medium as a control. The bottles were followed for 10 to 12 days in order to find out any cytopathogenic effects (CPEs).

Virus isolation in one out of four samples was characterized from the beginning, 12 to $24 \mathrm{~h}$, by rounding and detachment of cells dispersed over the monolayer. Approximately $48 \mathrm{~h}$ postinfection, the cells presented a kind of shrinkage and long cytoplasmic filaments, often seen in herpes-infected cell cultures. The CPE culminated in enlarged refringent cells and lytic degeneration. The enlarged cells also had long filaments with several balloons along their length (Figure 1).

Serum samples were probed against the isolated virus by a standard serum neutralization test as described by Bitsch (1978). Three of them were negative, and the one harvested from the same cow, from which a swab generated the isolated virus, had a positive result. It may be reasonable to assume that negative results are due to a biological property of this virus, in which cattle infected naturally or experimentally develop a humoral immune response characterized by the production of non-neutralizing antibodies. Or, if they are produced, serum has low titer, and antibodies are detectable between 22 and 34 days after infection (Castrucci et al., 1986). Frazier et al. (2001), using an endometriotropical viral stain isolated from cows with metritis and submitted to autopsy, reported that of 480 serum samples analyzed by neutralization, 404 were negative and 76 positive with titers ranging from $1: 8$ to $1: 32$. Using the same methodology for sera coming from enzootically infected animals from a dairy herd, they detected 107 (26\%) positive animals from a total of 296 , and the titers ranged from 1:8 to $1: 64$. Antibodies directed to non-critical antigens can be detected by indirect immunofluorescence reaction (IIFR), enzyme-linked immunosorbent assay (indirect ELISA), and immunoperoxidase, with serum conversion

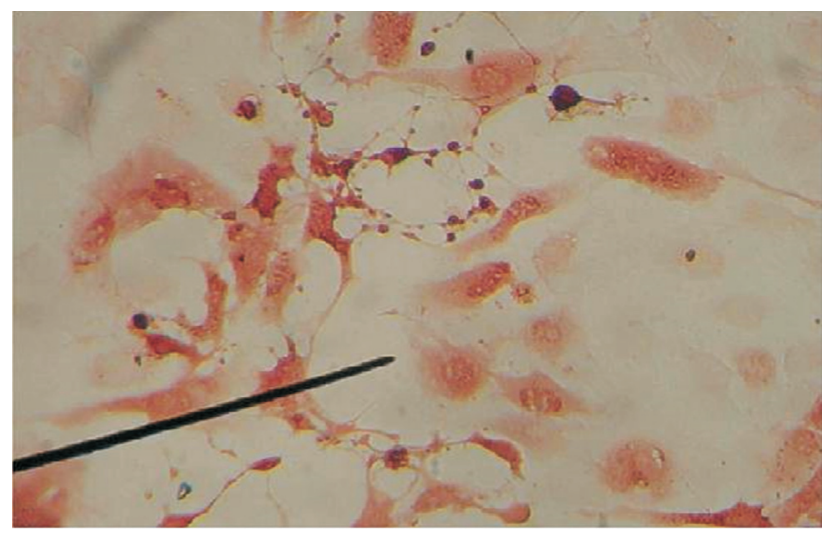

Figure 1 - BoHV-4/SU cytopathic effect on TraFB cells $7 \mathrm{~d}$ postinfection, $400 \mathrm{X}$ augmentation. 
occurring between 14 and 20 days after primary infection (Wellemans et al., 1999; Monge et al., 2006). As we did not have these approaches standardized, but only serum neutralization, at the time the research was under way, we preferred to invest in viral isolation and molecular characterization. Positive serum was also probed by serum neutralization against BoHV-1 and revealed a negative result.

Electron microscopy of the isolated virus was performed as follows: the putative virus isolate was multiplied further to allow visualization. When the CPE was generalized, from 5 to $7 \mathrm{~d}$, the bottles were frozen then thawed 3 times. Cell debris were removed by centrifugation $\left(10,500 \mathrm{xg}\right.$ for $10 \mathrm{~min}$ at $\left.4{ }^{\circ} \mathrm{C}\right)$, and the supernatant was concentrated to $1 / 10$ of the original volume in an Amicon filter (Amicon-Millipore, MA, USA) with membrane pores that had a 10-KDa exclusion limit.

The concentrate was applied to a $30 \%$ sucrose cushion and centrifuged at 100,000 x $g$ for $90 \mathrm{~min}$ in a Beckman ultracentrifuge (Beckman Coulter, CA, USA). The pellets were resuspended in TEN buffer $(100 \mathrm{mM} \mathrm{NaCl}, 10 \mathrm{mM}$ Trizma, and $1 \mathrm{mM}$ EDTA), pH 7.2, and a drop was laid on a 200-mesh carbon-coated electron microscopy grid. A drop of $2 \%$ phosphotungstic acid was added for 3 to $5 \mathrm{~min}$, and the excess liquid was removed with filter paper. The grids were visualized in a Jeol electron microscopy (Jeol, Tokyo, Japan) at $300 \times 103$ magnification. Visualization of the virus revealed structures with typical herpesvirus morphology, an icosahedral nucleocapsid, and existence of a well-defined membrane envelope (Figure 2).

Amplification of a segment of the viral genome, which included the 3 end of open reading frame ofORF 1 (homologous to the Epstein-Barr virus gene - EBV BVRF1), ORF 2 (homologous to the EBV BXRF1 gene), ORF 3 (thymidine kinase), and gH gene 5end ORF 4, was carried out by a polymerase chain reaction (PCR), a procedure described by Donofrio et al. (2000), with minor modifications. Briefly, a $1000 \mu \mathrm{L}$ sample of the semipurified virus was treated with $0.5 \%$ sodium duodecyl sulphate (SDS) and $100 \mu \mathrm{g}$ of proteinase $\mathrm{K} / \mathrm{mL}$ in a TEL buffer (10 mM Tris-HCl, pH 7.5, $1 \mathrm{mM}$ EDTA) at $56{ }^{\circ} \mathrm{C}$ for $1 \mathrm{~h}$. Three repeated DNA extractions were performed with phenol-chloroform-isoamyl alcohol (25:24:1) and twice with chloroform, followed by ethanol precipitation. For the remaining cycling conditions, reagent concentration, primers, restriction enzyme digestion, and

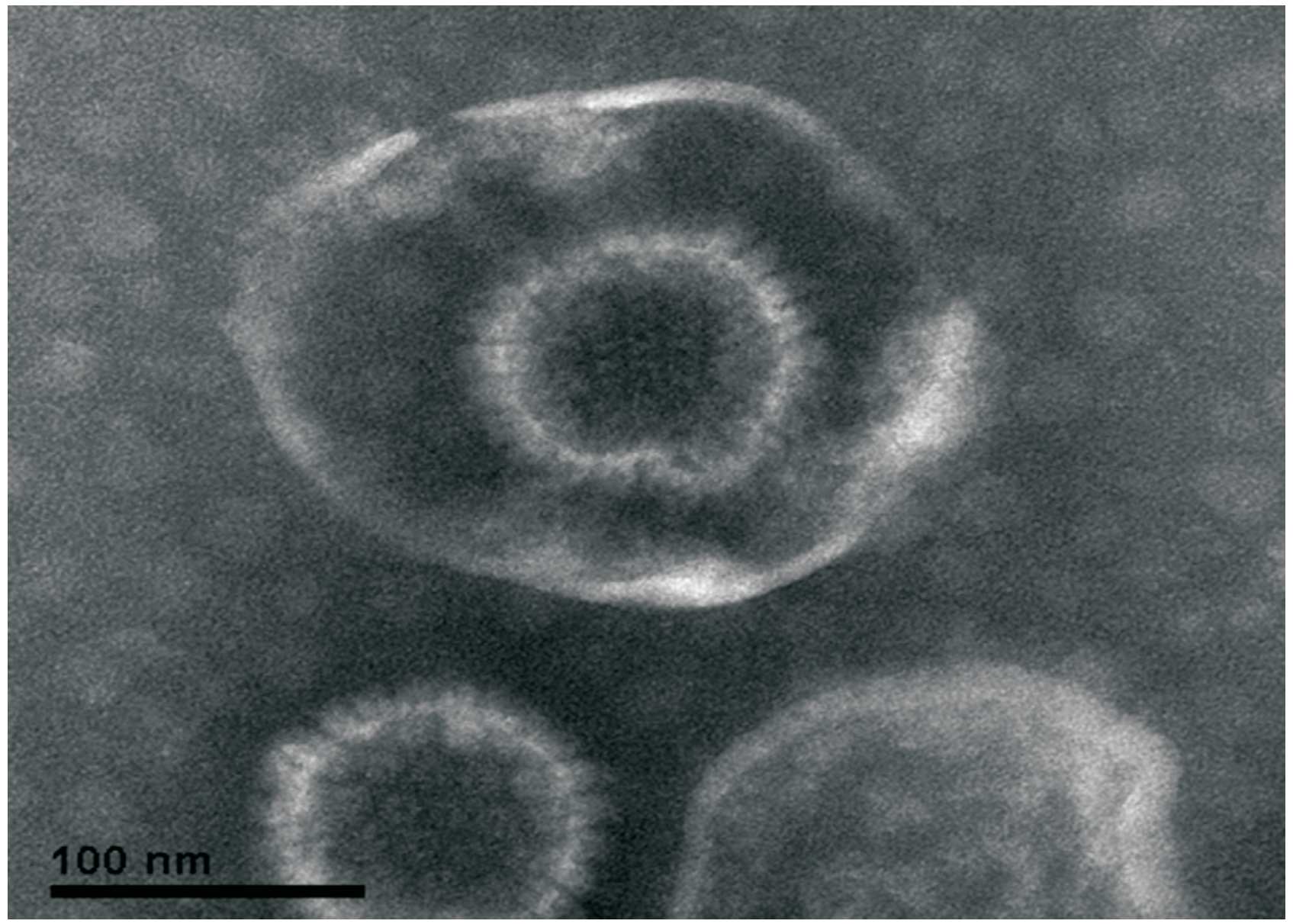

Figure 2 - BoHV-4/SU electron microscopy, 300 x 103 magnification. 
electrophoresis, the protocol was exactly the same (Donofrio et al., 2000). The amplified fragment had a molecular weight compatible with the predicted amplicon, assumed to be $2,571 \mathrm{bp}$, considering the band positioning between molecular weight marker bands 2 and $3 \mathrm{kbp}$.

Following HindIII digestion, this fragment generated four bands whose base pair contents were considered to have $403,420,535$, and $1,125 \mathrm{bp}$, based on the molecular weight marker bands and the similarity of the band migration patterns to results published in previous work (Donofrio et al., 2000).

DNA fingerprinting was performed as described by Osorio et al. (1985). In summary, $5 \mu \mathrm{g}$ of the extracted genomic DNA was digested with 20 units of each restriction enzyme, BamHI and $\operatorname{HindIII}$, at $37^{\circ} \mathrm{C}$ for $2 \mathrm{~h}$. The product of digestion was subjected to electrophoresis at $15 \mathrm{~V} / \mathrm{cm}$ in $0.8 \%$ agarose gel, then stained with ethidium bromide and visualized under a UV-photo documentation system.

The restriction enzymes generated cleavage products that are in agreement with the profiles assigned to BoHV-4, strain DN 599: a hypermolar fragment and 2,350 bp in size, indicating a class II monomeric repeat unit (Ehlers et al., 1985; Zimmermann 2001) and the total number of fragments ( $\mathrm{L}$ to $\mathrm{M}$ ) as a result of the BamHI treatment, while HindIII generated fragments of size and relative migration distance typical the above-mentioned strain (Figures 3 and 4).

The goal of this work was to definitively characterize a virus isolated from cows with postpartum metritis. Welldocumented biological properties, such as the nature and dynamics of cytopathic effect development, were the starting points. Initially, inoculated cell cultures presented en-

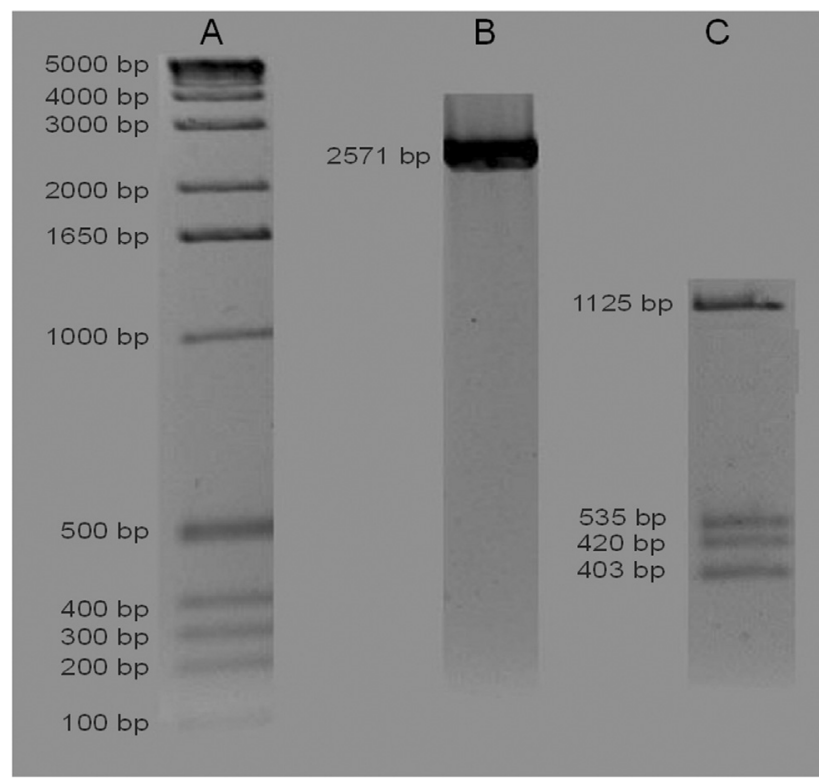

Figure 3 - BoHV-4/SU PCR amplicon in agarose gel (1.6\%) before and after HindIII digestion in electroforesis gel. Lane A: Molecular marker (1 kb gibcoBRL ladders ${ }^{\circledR}$ ); Lane B: BoHV-4/SU PCR amplicon bands; Lane C: Products from PCR amplicon following Hind III digestion.

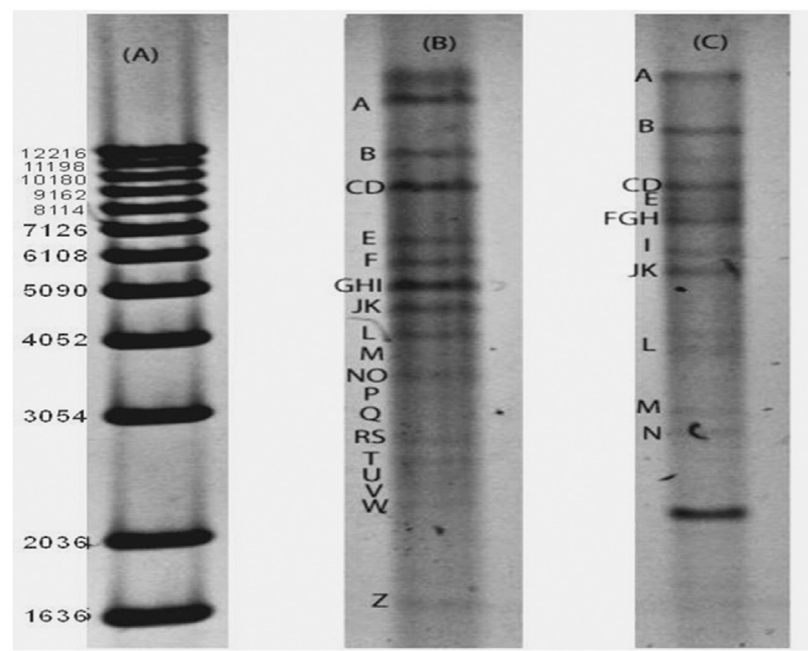

Figure 4 - BoHV-4/SU genome after Hind III and Bam HI digestion and subjected to electrophoresis at $15 \mathrm{~V}$ in $0.8 \%$ agarose. Lane A: molecular maker (1 kb plus invitrogen ${ }^{\circledR}$ leddar); Lane B: BoHV-4/SU Hind III digestion; Lane C: BoHV-4/SU Bam HI digestion.

larged cells dispersed over the monolayer. From $48 \mathrm{~h}$ postinfection, a sequence of morphological modifications were observed, such as emission of cell cytoplasmic elongations containing several small balloons along them and by $7 \mathrm{~d}$ postinfection, complete cell lysis had occurred. This kind of cytopathology was highly suggestive of a herpesvirus infection.

Analysis of negatively stained virus particles revealed morphology compatible with a herpesvirus in both size and shape. Also characteristic was the presence of an envelope loosely arranged around the nucleocapsid and some space between them containing protein structures not resolved by conventional electron microscopy that maintained the envelope separate from the nucleocapsid, as described by Theodoridis (1978) in his seminal paper on the new herpesvirus isolated in Africa, currently considered to be BoHV-4.

The genome evaluation by PCR, whose primer design is specific to BoHV-4, generated an amplicon that after HindIII digestion produced four fragments with a base pair composition in accordance with the reference methodology (Donofrio et al., 2000, 2007; Zimmerman et al., 2001). This experimental result allowed the isolated virus to be classified as BoHV-4. Restriction endonuclease analysis of viral DNA has been used as a tool to discriminate between virus strains that share biological and immunological properties. Taking in account the three classes of BoHV-4 polyrepetitive DNA (prDNA) determined by the total sizes of hypermolar fragments and the number and migration patterns of the digestion products, two restriction enzymes that are present in almost all the methodologies of similar works were chosen (Osorio et al., 1985, Donofrio et al., 2000). As shown in Figure 4, BamHI produced the typical hypermolar band of class II prDNA, 2,350 bp, and HindIII 
produced the designated diagnostic bands. From the above-mentioned data, amplicon size generated by PCR and its restriction enzyme profile in addition to the hypermolar class II prDNA generated by BamHI treatment, it was possible to conclude that the viral agent involved and characterized was BoHV-4 appertaining to a DN599 group. Such a virus strain has been designated BoHV-4/SU.

In Brazil, there are no published studies on BoHV-4 isolation; only recently Costa et al. (2011), using a molecular methodology, reported BoHV-4 genome in 14 fragments of the CNS in cattle that presented neurological signs in the southeast region (Minas Gerais). However, the authors did not isolate the virus.

Association between BoHV-4 and reproductive disorders is a well-documented issue, but it deserves special attention when the occurrence of this pathogen is in South America, a geographic region where there have been a few studies of it.

\section{References}

Bartha A, Juhasz M, Liebermann H (1966) Isolation of a bovine herpes virus from calves with respiratory disease and keratoconjunctivitis. A preliminary report. Acta Vet Acad Sci Hung 16:357-358.

Bitsch V (1978) The p37\24 modification of the infectious bovine rhinotracheitis virus-serum neutralization test. Acta Vet Scand 19:497-505.

Castrucci G, Frigeri F, Cilli V, Donelli G, Ferrari M, Chicchini U, Bordoni E (1986) A study of a herpesvirus isolated from dairy cattle with a history of reproductive disorders. Comp Immunol Microbiol Infect Dis 9:13-21.

Costa EA, Vasconcelos AC, Bomfim MRQ, Amorim HB, Lima GBL, Coelho FM, Resende M (2011) Disorder in cattle associated with bovine herpesvirus 4. Arq Bras Med Vet Zoot 63:828-835.

Czaplicki G, Thiry, E (1998) An association exists between bovine herpesvirus- 4 seropositivity and abortion in cows. Prev Vet Med 33:235-240.

Donofrio G, Cavirani S, Flammini CF, Scatozza F (2000) Molecular typing of a bovine herpesvirus 4 field isolate. Vet Res Commun 24:411-422.

Donofrio G, Herath S, Sartori C, Cavirani S, Flammini CF, Sheldon IM (2007) Bovine herpesvirus 4 is tropic for bovine endometrial cells and modulates endocrine function. Reprod 134:183-187.

Ehlers B, Buhk HJ, Ludwig H (1985) Analysis of bovine cytomegalovirus genome structure: cloning and mapping of the monomeric polyrepetitive DNA unit and comparison of European and American strains. J Gen Virol 66:55-68.

Frazier K, Pence M, Mauel MJ, Liggett A, Hines II ME, Sangster L, Lehmkuhl HD, Miller D, Styer E, West J, Baldwin CA (2001) Endometritis in post parturient cattle associated with bovine herpes virus-4 infection: 15 cases. J Vet Diagn Invest 13:502-508.

Markine-Goriaynoff N, Minner F, DeFays K, Gillet L, Thiry E, Pastoret PP (2003) Vanderplasschen A. L'herpèsvirus bovin 4. Ann Méd Vét 147:215-247.

Mehrotra ML, Schucla DC, Srivastava NC (1986) Isolation of a new herpes virus from cases of reproductive disorders in cows. Indian J An Sci 56:1196-1199.

Mohanty SB, Hammond RC, Lillie MG (1971) A new bovine herpes virus and its effects on experimentally infected calves. Arch Gesamte Virusforsch 34:394-395.

Monge A, Elvira L, Gonzales JV, Astiz S, Wallenberg GJ (2006) Bovine herpesvirus-4 associated postpartum metrites in a Spanish dairy herd. Res Vet Sci 80:120-125.

Nikolin V, Donofrio G, Milosevic B, Taddei S, Rodosavljevic V, Milicevic N (2007) First Serbian isolates of bovine herpesvirus-4 (BoHV-4) from a herd with history of postpartum metritis. New microbial 30:53-57.

Osorio FA, Reed DE, Van der Maaten MJ, Metz CA (1985) Comparison of the herpes virus of cattle by DNA restriction endonuclease analysis and serological analysis. Am J Vet Res 46:2104-2109.

Parks JB, Kendrick JW (1973) The isolation and partial characterization of a herpes virus from a case of bovine metritis. Arch Gesamte Virusforsch 41:211-215.

Theodoridis A (1978) Preliminary characterization of viruses isolated from cases of epididymitis and vaginitis in cattle. Onderstepoort J Vet Res 45:187-195.

Verna AE, Leunda MR, Louge Uriate E, Lomonaco M, Pereyra S, Ódeon AC (2008) Primera evidencia virológica de Herpesvirus bovino tipo 4 (BoHV-4) en Argentin. Rev Arg Microbiol 54-55.

Wellemberg GJ, Van Rooij EM, Maissan J, Van Oirschot JT (1999) Evaluation of a newly developed immunoperoxidase monolayer assay for detection of antibodies against bovine herpesvirus 4. Clin Diagn Lab Immunol 6:447-451.

Zimmermann W, Broll H, Ehlers B, Bulk HJ, Rosenthal A, Goltz M (2001) Genome sequence of bovine herpesvirus-4, a bovine rhadinovirus, and identification of an origin of DNA replication. J Virol 753:1186-1194.

Associate Editor: Odir Antonio Dellagostin

All the content of the journal, except where otherwise noted, is licensed under a Creative Commons License CC BY-NC. 